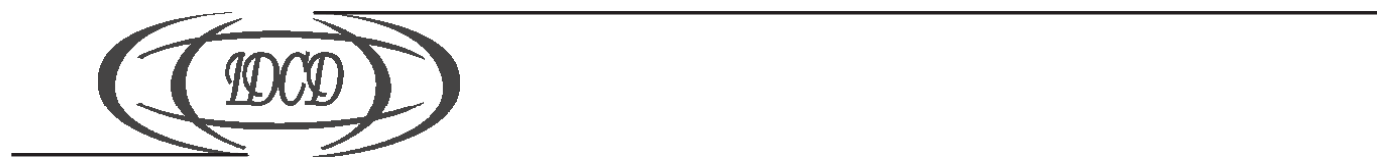

УДК 314(474.5)+316.346.2-055.2(474.5)

\author{
V. STANKUNIENE, \\ Prof. Dr., leading researcher, \\ Lithuanian Social Research Centre, Vilnius, Lithuania, \\ Gostauto str. 11, LT-01108, Vilnius, Lithuania \\ E-mail: v.stankuniene@smf.vdu.lt
}

\author{
M. BAUBLYTE, \\ Researcher, Lithuanian Social Research Centre, \\ Vilnius, Lithuania, \\ Gostauto str. 11, LT-01108, Vilnius, Lithuania \\ E-mail:m.baublyte@smf.vdu.lt
}

\title{
SOCIODEMOGRAPHIC DIFFERENCES OF FERTILITY INTENTIONS IN LITHUANIA IN THE CONTEXT OF LOW FERTILITY AND ECONOMIC INSTABILITY
}

The article is devoted to investigate sociodemographic differences of fertility intentions in Lithuania within the context of lowering and low fertility and changing economic situation. To reveal the dynamics of fertility intentions the findings obtained from the several international and national surveys carried out in Lithuania over the last fifteen years have been used for the analysis.

Key words: fertility; fertility intentions; sociodemographic fertility differences, Lithuania.

Introduction and significance. During the last two decades the fertility pattern of Lithuania has been undergoing essential changes. In the early 1990s fertility in Lithuania started lowering and within a few years dropped drastically to the lowest low level. A consistent increase of fertility rates which has been observed since 2005 and which, to this day, does not allow Lithuania to escape the range of the low fertility, should be basically associated with the fertility postponement process. The fertility changes of Lithuania are most similar to those of the other Central and Eastern European countries which, in addition to the various specific factors - economic, social and transformational-period, were affected the strongest by the factors which in Western Europe had initiated the changes several decades earlier and which had been included into the theoretical framework of the second demographic transition explaining the mechanism of the new fertility pattern.

Childbearing attitudes are an important element of fertility change. Whether the childbearing attitudes are changing alongside the essentially changing socio-economic and cultural conditions and how this change occurs in different socio-demographic sub-populations, is an 
important question both at the theoretical and practical level, which could offer clarification of the current fertility situation. The research emphasises that disclosure of childbearing attitudes is highly instrumental in foreseeing further fertility changes and enables to assess the likely fertility level in the near and remote future, at least within the already examinable thirty-year period [10].

The fertility level and childbearing attitudes are concurrently affected by micro- and macro-factors which reflect not only the current condition, but reach back into the past and are related to the future. And the relationship also depends on the demographic regime and its change. As noted by Testa and Grilli [19], childbearing attitudes depend on the demographic regime and its typical fertility model, which is reflected in the childbearing preferences and behaviour of the cohorts: childbearing attitudes depend on the demographic regime at the time of the cohort's growth, which with the decreasing fertility acquires lower childbearing attitudes. This predetermines a smaller number of children in the subsequent cohorts. Thus socialization of a young cohort in the environment of progressively lowering number of children has a lowering effect on the childbearing attitudes and also on the behaviour [9].

Research of childbearing attitudes is also important since comparison of their indicators with the real facts, i.e. actual family size, supplies information on the (un)suitability of the contextual environment (at macro- and micro-levels) for realisation of the attitudes. A significant deviation of childbearing attitudes from the actual indicators of fertility behaviour signifies unfavourable conditions for families' aspiration to strive to childbearing goals and to have a planned number of children. This is an important message for the designers of family policy, who are drafting a family-friendly pronatal policy bringing it closer to the needs of different socio-demographic groups and substantiating the targeted fertility indicators and their likely shift.

This is one of the main reasons why as of late research of fertility attitudes and intentions has been given increasingly more emphasis. Questions on fertility attitudes and intentions have been included into the questionnaires of the major international comparative surveys on family and fertility of the last two decades: longitudinal Generations and Gender Survey (ongoing since the beginning of this century), Population Policy Acceptance Study (conducted in the beginning of 2000s). Information of such kind has also been accumulated within the framework of the European Value Study. Basing on the findings of the survey a number of works containing empirical as well as conceptual ideas have been published $[5 ; 8 ; 16 ; 17$; and others). Considerable attention has been attached to the assessment of the effect of fertility attitudes on the fertility level. Importance of such information for policy makers has been noted by numerous researchers of fertility and family policy $[7 ; 10 ; 16 ; 15 ; 17 ; 18])$.

However, a lot of rather controversial conclusions both on usefulness of the information concerning the quantities measurements of fertility attitudes and on formation of family policy have been voiced $[17 ; 16 ; 14 ; 19 ; 4 ; 5 ; 11]$, more so that different researches have documented significant differences between the ideal, desired and actual number of children $[5 ; 8 ; 12 ; 14]$.

In the countries which belonged to the former USSR research of fertility attitudes and differentiation thereof has an experience reaching far back into the past. The results of the surveys conducted as early as the 1960s and later years are summed up in the acknowledged works by Belova, Darskij, Bondarskaja [1;2;3], and others.

The article aims to investigate childbearing attitudes and intentions and their socio-demographic differences in Lithuania in the context of low fertility and the unstable economic situation. 
Data and methods. For disclosure of changes in Lithuanian fertility intentions the research uses the data from the surveys conducted within the last fifteen years: international Fertility and Family Survey (initiated and coordinated by United Nations Economic Commission for Europe, Population Activities Unit; conducted in more than 20 countries; in Lithuania - in 1994-1995), first and second waves of Generations and Gender Survey (initiated and coordinated by United Nations Economic Commission for Europe, Population Activities Unit; conducted in Lithuania - in 2006 and 2009), Population Policy Acceptance Study (coordinated by Federal Institute for population Research, Wiesbaden, Germany; conducted in 14 countries; Lithuania - in 2001) and national survey Needs of Family Policy (2010). For the analysis the data of answers to identical questions on the desired and intended number of children and on fertility intentions within the next three years are used. For evaluation of changes on the intended number of children the data of the 1994-1995 and 2010 surveys and on the desired number of children, the 2001, 2006, 2009 and 2010 surveys have been used. A descriptive and logistic regression analysis has been applied for the appraisal of changes in sociodemographic fertility intentions.

Results. The findings of the surveys conducted around the last fifteen years (1994-2010) show that not only fertility has decreased in Lithuania but fertility intentions have been shifting towards decline, too. During the fifteen years since the mid-1990s the mean desired number of children among the 18-49 year-olds (both men and women) who already have and/or desire to have children has fallen from 2.09 (in 1994-1995) to 1.99 (in 2010), while among the total population of this age the change is from 1.84 to 1.81 .

The number of children intended to have which at the turn of this century was still close to the replacement level, has fallen, within the decade, far below two children: among the $18-49$ year-olds the mean number of children intended to have fallen from 1.91 in 2001 to 1.75 in 2010 (Fig. 1).

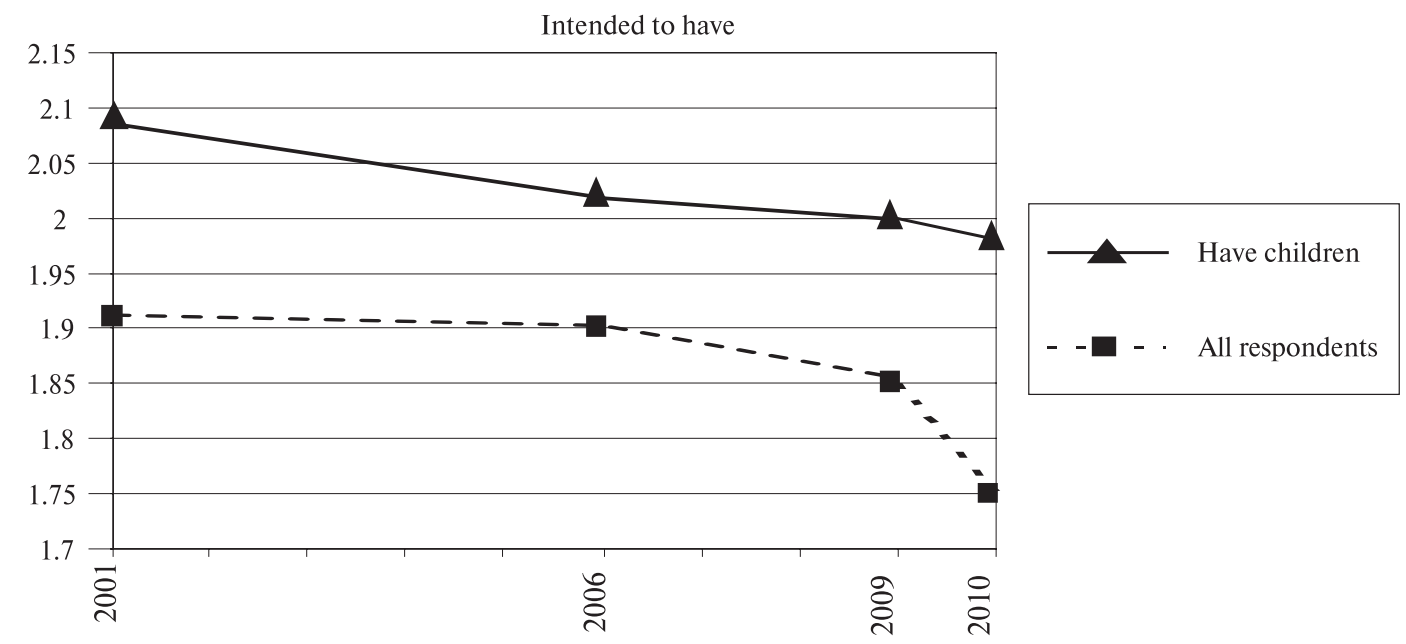

Fig. 1. Mean number of children intended to have. Respondents of 18-49 years old

Sources: Generations and Gender Survey: first wave - 2006, second wave - 2009; Population Policy Acceptance Study - 2001; Needs of Family Policy - 2010. 
Table 1. Mean number of children intended to have. Men and women of 18-49 years old

\begin{tabular}{|l|c|c|c|c|}
\hline & $\mathbf{2 0 0 1}$ & $\mathbf{2 0 0 6}$ & $\mathbf{2 0 0 9}$ & $\mathbf{2 0 1 0}$ \\
\hline A. Mean number of children intended to have (all respondents) \\
\hline Men & 1.96 & 1.88 & 1.83 & 1.68 \\
\hline Women & 1.87 & 1.91 & 1.87 & 1.81 \\
\hline Total & 1.91 & 1.90 & 1.85 & 1.75 \\
\hline B. Mean number of children inter ded to have (respondents with children / want to have children) \\
\hline \multicolumn{7}{|l|}{ Men } & 2.16 & 2.04 & 2.01 & 1.99 \\
\hline Women & 2.03 & 2.00 & 2.00 & 1.96 \\
\hline Total & 2.09 & 2.02 & 2.00 & 1.98 \\
\hline
\end{tabular}

Sources: Generations and Gender Survey: first wave - 2006, second wave - 2009; Population Policy Acceptance Study - 2001; Needs of Family Policy - 2010.

Differences between fertility intentions of men and women are considerable. Although the development trend of fertility intentions of men and women is similar, the rates and the change trajectory are considerably different: intended fertility rates of men which had been higher in 2001, were falling consistently and to a larger extent in over the period of 2001-2010 (2001, 2006, 2009 and 2010 survey data), whereas among women they were slowly moving, with slight fluctuations, towards decline and according to the data of the last survey (2010) are higher than those of men: for 18-49 years men the mean intended number of children has declined from 1.96 to 1.68 , and for women - from 1.87 to 1.81 (Table 1).

The 2006, 2009 and 2010 survey data enable to make an analysis of the differences and changes in the fertility intentions, i.e. mean intended to have number of children, of different socio-demographic and socio-economic groups within the context of the unstable macroeconomic development.

The 2006 survey data reflected the fertility attitudes preconditioned by the economic upswing: feeling of economic stability and prosperity, hopes for making long-term plans favourable for family planning, whereas the 2009 data reflected a clash with a threat of economic recession, and the 2010 - actual negative consequences of the economic crisis at the national, family and individual levels.

A descriptive and logistic regression analysis performed shows correlation between fertility intentions and age, education, employment status and residence. With the change of the macro-economic situation the strength of the factors was also changing which resulted in different impact on the fertility intentions of various sociodemographic groups.

An evaluation of fertility intentions in the context of macroeconomic fluctuations has revealed an unmistakable reaction of the youngest men and women to economic difficulties: mean number of intended to have children of the men aged 20-29 years decreased from 1.97 in 2006 to 1.84 in 2009 and as low as to 1.67 in 2010, of women - correspondingly from 2.07 to 2.05 and even to 1.78 (Fig. 2).

The highest fertility intentions are observed among the men with university education. According to the 2006, 2009 and 2010 survey data fertility intentions of men with higher education are not affected even by economic fluctuations - they are steadily oriented to an average family of two children. Meanwhile the men with lower education who during the periods of economic instability usually face uncertainty on the labour market and in assuring 
the family wellbeing, have lower fertility intentions, thus during economic downturn they favour an even smaller number of children (Fig. 3).

According to the 2006 data the indicators of fertility intentions among women with different education were actually equal (mean number of intended to have children - 1.92-1.93). During the period of economic downturn fertility intentions of women were also experiencing a shift toward decrease, but the variation depended on education: the fertility intentions of women with university and secondary education were decreasing, while those of lower than secondary educated even rose.

Findings on differentiation of fertility intentions by employment status confirm that men and women response to economic instability and unemployment differently, particularly in the societies with firm standards of traditional gender roles [6]. Fertility intentions of men who have a job are higher than of women, irrespective of the economic situation in the country. The personal factors which ensure their economic stability, employment and income from employment, are highly important in making childbearing plans. However, during hardship periods, these are adjusted significantly: the mean number of intended to have children of employed men was 1.93 in 2006, 1.75 in 2010 (Fig. 4). Vague prospects for the future make them be more cautious in planning a family. Meanwhile unemployed men have considerably smaller childbearing plans, irrespective of the overall macroeconomic situation: the findings of the Lithuanian survey evidence that for men losing a job is a factor of paramount importance which adjusts the fertility behaviour and intentions [13].


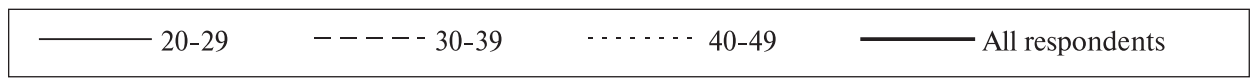

Fig. 2. Mean number of children intended to have by age of respondents 

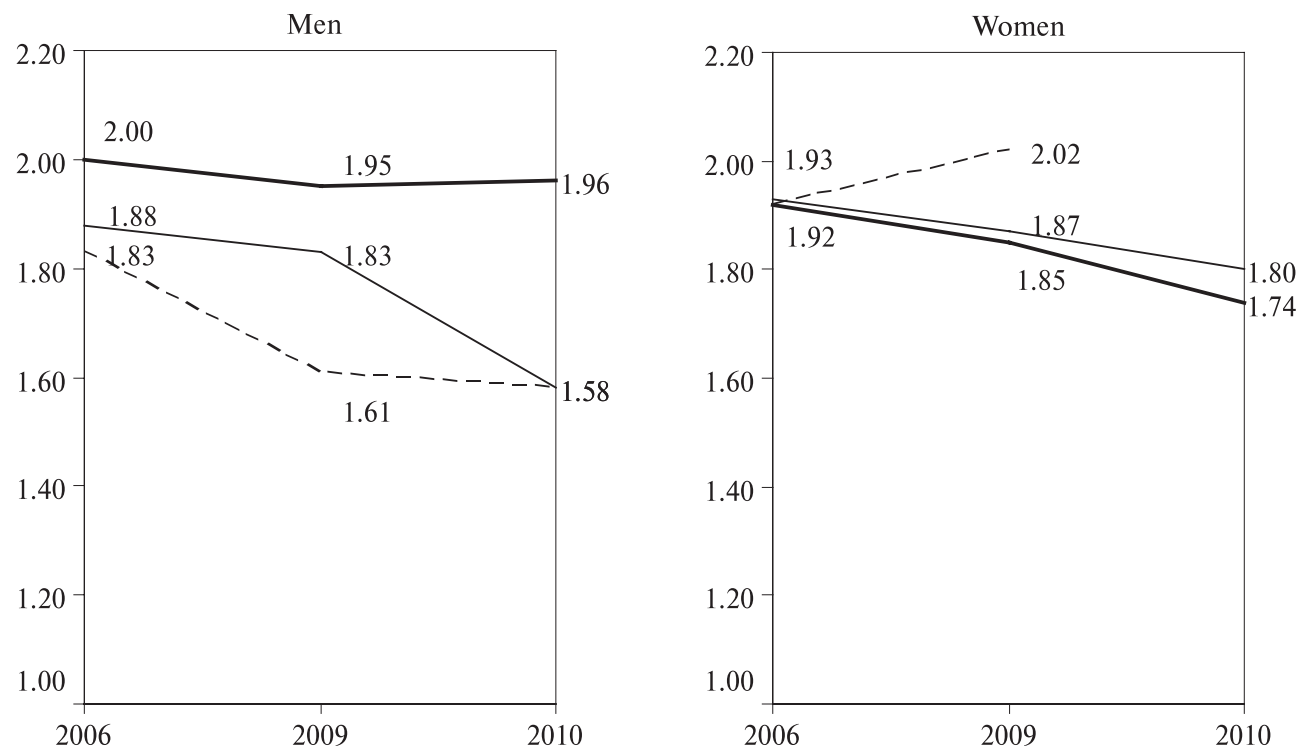

Higher

Secondary

Lower than secondary

Fig. 3. Mean number of children intended to have by education level of respondents. Respondents of $20-49$ years old

The fertility intentions of working women are lower than of men and are considerably less affected by the macroeconomic situation, and with the unemployed, they have a totally different model from that of men: first, they are considerably higher; second, even in the context of economic fluctuations they have a different trajectory of the change - oscillation with no expressed decrease trend.

The differences in fertility intentions by residence and changes thereof in the context of fluctuating economic development demonstrate, first, great dependence of intentions on the type of residence, its economic dynamism, the social infrastructure provided and a chance to ensure the children's and family wellbeing therein. Second, this reveals sub-populations by the type of residence affected the most severely by the recent economic instability. Vilnius, capital of Lithuania stands out, conspicuously, by the highest fertility intention indicators. The mean number of intended to have children both among men and women, according to the data of the surveys under analysis which provide information on the periods of economic upswing and downturn, is the largest in Vilnius and actually is on replacement level - 2.02-2.19 (Fig. 5). Even during the years of the most intensive economic decline the indicator equalled 2 in Vilnius. In all other residential areas fertility intentions of both men and women were much lower and besides, during the economic recession they were subject to a much stronger adjustment.

An analysis of logistic regression was performed in order to distance away from the structural changes and to appraise the factors which may encourage 20-39 years men and women with no children for intention of having two or more children. 

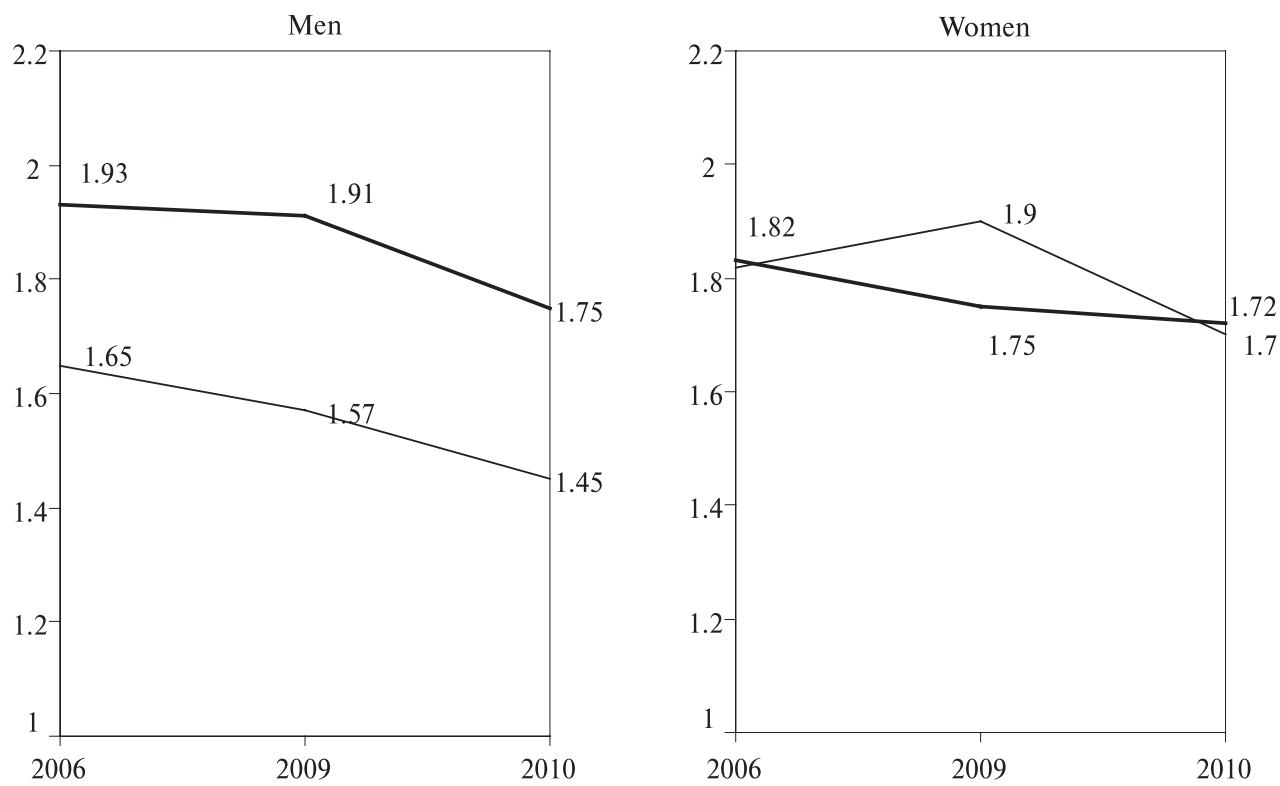

Fig. 4. Mean number of children intended to have by employment status of respondents. Respondents of 20-49 years old
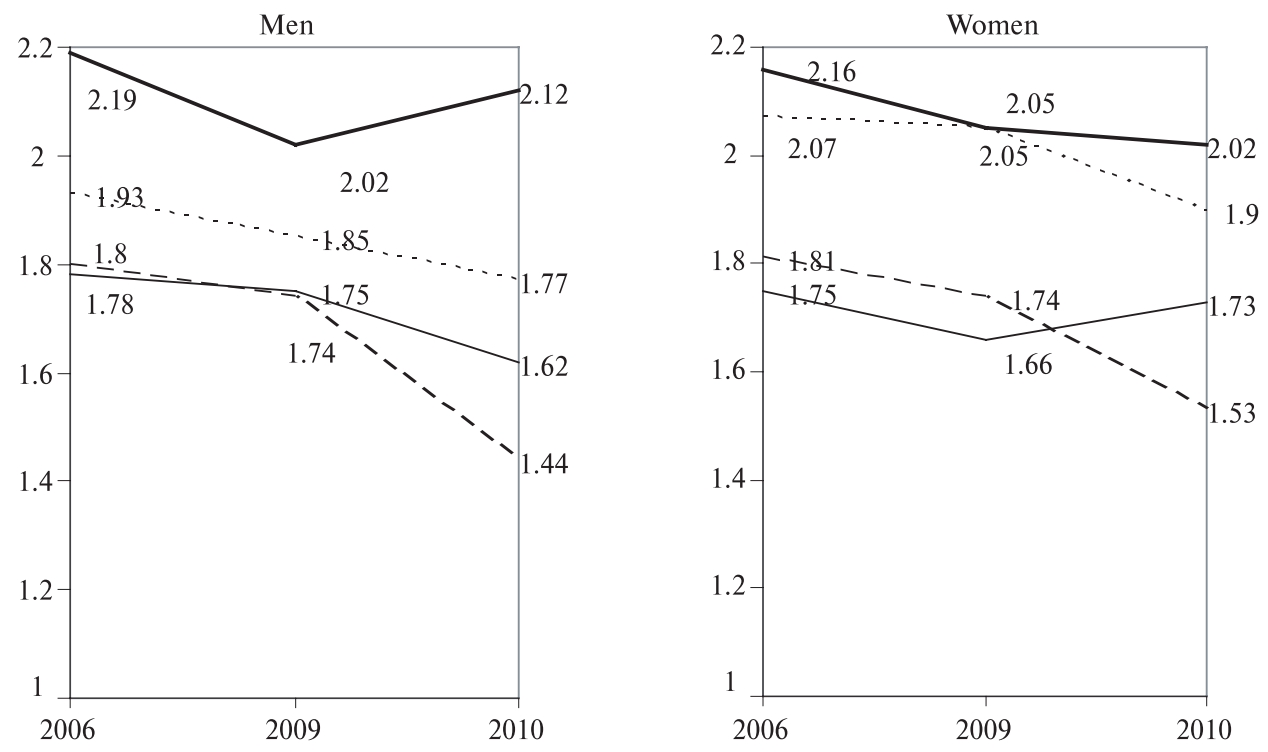

Vilnius $>100$ thaus. $-----10-100$ thaus. $<10$ thaus.

Fig. 5. Mean number of children intended to have by residence. Respondents of 20-49 years old 
The analysis of logistic regression revealed a considerably large difference of impact factors on fertility intentions by gender (Table 2). The intentions of men with no children to have two and more children are much more susceptible to economic factors than of women and this is most evident during the period of economic downturn.

Table 2. Factors of intentions to have two children. 20-39 years old childless respondents

\begin{tabular}{|c|c|c|c|c|}
\hline \multirow[t]{3}{*}{ Factors } & \multicolumn{4}{|c|}{ Odds ratio $\operatorname{Exp}(B)$} \\
\hline & \multicolumn{2}{|c|}{2006} & \multicolumn{2}{|c|}{2009} \\
\hline & Men & Women & Men & Women \\
\hline \multicolumn{5}{|l|}{ Age } \\
\hline $20-24$ & 1 & 1 & 1 & 1 \\
\hline $25-29$ & $0,536^{* *}$ & 0,761 & $0,572^{*}$ & $0,428 * *$ \\
\hline $30-34$ & $0,205^{* * *}$ & $0,202^{* * *}$ & $0,267 * * *$ & $0,133^{* * *}$ \\
\hline $35-39$ & $0,070^{* * *}$ & $0,045^{* * *}$ & $0,063^{* * *}$ & $0,042^{* * *}$ \\
\hline \multicolumn{5}{|l|}{ Marital status } \\
\hline Married & 1 & 1 & 1 & 1 \\
\hline Cohabitation & $0.416^{* *}$ & $0.351^{* *}$ & 0.787 & 1.025 \\
\hline Other1 & $0.455^{* *}$ & $0.321^{* * *}$ & $0.442^{*}$ & 0.656 \\
\hline \multicolumn{5}{|l|}{ Education } \\
\hline Higher & 1 & 1 & 1 & 1 \\
\hline Secondary & 1.036 & 0.819 & 1.314 & $0.537 * *$ \\
\hline Lower than secondary & 0.676 & 1.208 & $0.415^{* *}$ & 0.369 \\
\hline \multicolumn{5}{|l|}{ Residence } \\
\hline$>10000$ & 1 & 1 & 1 & 1 \\
\hline $10001-100000$ & 1.032 & 0.603 & 0.775 & 0.892 \\
\hline $100001-500000$ & 1.182 & 0.958 & $0.616^{*}$ & 0.792 \\
\hline Vilnius & $3.733^{* * *}$ & $5.356^{* * *}$ & $1.892^{*}$ & $2.278^{*}$ \\
\hline \multicolumn{5}{|l|}{ Dwelling } \\
\hline Have 1 room & 1 & 1 & 1 & 1 \\
\hline Have 2 rooms & 0.917 & 0.815 & 1.373 & 1.080 \\
\hline Have 3 rooms & 1.231 & 0.862 & 1.643 & 1.206 \\
\hline Have 4 and more rooms & 1.755 & 1.167 & 1.299 & 0.995 \\
\hline \multicolumn{5}{|c|}{ Estimations of household's total monthly income: is household able to make ends meet } \\
\hline Very easily + easily & 0.879 & 0.836 & 1.892 & 1.503 \\
\hline Fairly easily & 1.327 & 0.604 & $2.541^{* * *}$ & 1.133 \\
\hline With some difficulty & 1.164 & $0.476^{*}$ & 1.529 & 1.292 \\
\hline With great difficulty + with difficulty & 1 & 1 & 1 & 1 \\
\hline
\end{tabular}




\begin{tabular}{|l|c|c|c|c|}
\hline \multirow{2}{*}{ Factors } & \multicolumn{4}{c|}{ Odds ratio $\operatorname{Exp}(\mathbf{B})$} \\
\cline { 2 - 5 } & \multicolumn{2}{|c|}{$\mathbf{2 0 0 6}$} & \multicolumn{2}{c|}{2009} \\
\cline { 2 - 5 } & Men & Women & Men & Women \\
\hline What other people might think about your having a/another child during the next three years1 \\
\hline Everyone thinks that you should have children & $1.543^{*}$ & 1.491 & 1.228 & $2.037^{*}$ \\
\hline Neither should or should not have & 1 & 1 & 1 & 1 \\
\hline Everyone thinks that you should not have children & 0.794 & 1.358 & $0.624^{*}$ & 1.310 \\
\hline
\end{tabular}

Significance level: $* 5$ (per 100), ** 1 (per 100) ir *** 1 (per 1000).

1Integrated factor. Statements about what other people might think about your having a/another child during the next three years:

a. Most of your friends think that you should have a/another child

b. Your parents think that you should have a/another child

c. Most of your relatives think that you should have a/another child

Possible answers: strongly agree; agree; neither agree nor disagree; disagree; strongly disagree;

Everyone thinks that you should have children: a, b, c = (strongly agree+agree)

Everyone thinks that you should not have children: $\mathrm{a}, \mathrm{b}, \mathrm{c}=$ (disagree + strongly disagree)

Neither should or should not be: all other combinations of $a, b, c$.

During an economic downturn an evident dependence of childless men's intentions to have more than one child on the economic wellbeing of the family is revealed. The ones with the income enabling comfortable living in comparison with the ones who state that the income permits them just basic living or hard living, during the 2009 survey expressed an intention to have two and more children twice and a half times more frequently. Also, among these men became evident dependence of their intention to have more than one child on their residence. During the economic upswing (2006) the men residing in Vilnius were singled out much more frequently (nearly four times, and with a high level of reliability) by the intention to have more than two children. Although during the years of decline (2009) these intentions were voiced less frequently, nevertheless, the difference by residence re-mained significant.

Within the context of economic fluctuation the correlation of fertility intentions of men with no children and education was changing importantly. During the economic upswing (2006), correlation of fertility intentions of men with no children to have more than one child and education was not observed, while during recession (2009), among lower-educated such intentions were recorded steadily and were significantly lower (more than twice lower than among university graduates).

Among the women who do not have children yet, a strong and consistent correlation between fertility intentions to have more than one child and residence has been observed. According to the 2006 survey, the residents of Vilnius, to compare with village and small town residents stated more than five times more frequently an intention to have two and more children, and in 2009 - more than twice more frequently.

During economic downturn (2009), observed fertility intentions of secondary-educated women with no children to have two and more children were twice as low as those of women with university education.

A short-term fertility intention (three years) analysis has shown a small number of firmly determined to have a child within the next three years. Such intentions were expressed slightly more frequently by the women aged 25-39 years. During economic decline such intentions became even more infrequent. In 2009, only 13-15 per cent of 25-39 year-old 
women stated a firm (definitely yes) intention to have children within the next three years. A high portion of respondents express uncertainty (answers probably yes, probably no) about having children within the next three years, and during the recession period this portion increased even more.

The analysis of logistic regression performed has revealed the greatest correlation of the fertility intentions to have children within the next three years with age and education. Men and women with higher education express much more positive short-term fertility intentions than the respondents with other educational background. A worsened macroeconomic situation increases the differences of fertility intentions by education even more: the gap between the university-educated from the lower-educated by the positive short-term fertility intentions becomes wider still.

Conclusions. Within the last twenty years, a greatly lowered and persisting low fertility in Lithuania has been accompanied by declining fertility intentions, which already are well below the replacement level and are strongly differentiated by socio-demographic groups. Bearing in mind the fact that the actual number of children is usually much smaller than the intended one, positive fertility changes are hardly to be expected in the future. Besides, high sensitivity of fertility intentions to fluctuations of economic development that has been revealed, increases considerably differentiation of the intentions and during economic decline is most severely felt among the socially vulnerable groups. By fertility intentions, subpopulations with a lower and strongly economic fluctuation-susceptible level are low-educated men, unemployed men and village and small town residents. Childbearing intentions of men living in the capital are high and remain practically stable within the context of macroeconomic fluctuations. Differences of women fertility intentions by sociodemographic groups are smaller and their reaction to macro-economic changes is rather controversial.

This study was funded by a grant (No. VP1-3.1-SMM-07-K-02-067) from the Research Council of Lithuania.

\section{ЛИТЕРАТУРА}

1. Белова В.А. (1975). Число детей в семье. Москва.

2. Белова В.А., Бондарская Г.А., Вишневский А.Г., Дарский Л.А., Сифман Р.И. (1977). Сколько детей будет в советской семье (результаты обследования). Москва: Статистика.

3. Белова В.А., Дарский Л.А. (1972). Статистика мнений в изучении рождаемости. Москва.

4. Berrington A. (2004). Perpetual postpones? Women's, men's and couple's fertility intentions and subsequent fertility behaviour. Population Trends 117.

5. Goldstein J., Lutz W., Testa M.R. (2003). The Emergence of Sub Replacement Family Size Ideals in Europe. European Demographic Research papers 2.

6. Kreyenfeld M. (2005). Economic uncertainty and fertility postponement. Evidence from German panel data. MPIDR Working paper WP 2005-034.

7. Letablier M.-T. Thevenon O. (2009). Trends in fertility and the effectiveness of policies for the realisation of family projects. The Cost of Raising Children and the Effectiveness of Policies to Support Parenthood in European Countries: A Literature Review. European Commission.

8. Liefbroer A.C. (2009) Changes in fertility size intentions across young adulthood: a life-course perspective. European Journal of Population. 25(4).

9. Lutz W., Skirbekk V., Testa M.R. (2006). The low fertility trap hypothesis. Forces that may lead to further postponement and fewer births in Europe. Vienna Yearbook of Population Research, 2006.

10. Miller W.B. (2011). Differences between fertility desires and intensions: implications for theory, research and policy. Reproductive decision-making. Vienna Yearbook of Population Research. Vol. 9. 
11. Morgan S.P. (2001). Should fertility intentions inform fertility forecasts? The Direction of Fertility in the United States.

12. Noack T., Ostby L. (2002). Free to Choose - but Unable to Stick to It. Dynamics of Fertility and Partnership in Europe 2. New York, Geneva: United Nations.

13. Phaile A., Solaz A. (2012). The influence of employement uncertainty on childbearing in France: A tempo or quantum effect? Demographic Research. Vol. 26/1.

14. Philipov D., Thevenon O., Klobas J., Bernardi L., Liefbroer A. (2009). Reproductive decision-making in a macro-micro perspective (REPRO): State-of-the-art review. European Demographic Research Papers 1.

15. Rossier C. Brachet S., Salles A. (2011). Family policies, norms about gender roles and fertility decisions in France and Germany. Reproductive decision-making. Vienna Yearbook of Population Research. Vol. 9.

16. Sobotka T. (2011). Reproductive decision-making in a macro-micro perspective (REPRO): Synthesis and Policy Implications. European Demographic Research Papers 1.

17. Testa M.R. (2012). Family size in Europe: Evidence from the 2011 Eurobarometer Survey. European Demographic Research Papers. No 2. Vienna Institute of Demography of the Austrian Academy of Sciences.

18. Testa M.R., Sobotka T., Morgan P. S. (2011). Reproductive decision-making: towards improved theoretical, methodological and empirical approaches. Reproductive decision-making. Vienna Yearbook of Population Research. Vol. 9.

19. Testa M.R., Grilli L. (2009). The effects of childbearing regional contexts on ideal family size in Europe: A multilevel analysis. European Demographic Research Paper. Vienna Institute of Demography of the Austrian Academy of Sciences.

\section{REFERENCES}

1. Belova V.A. (1975). Chislo detei v semie. [The number of children in family]. Moscow: Statistika [in Russian].

2. Belova V.A., Bondarskaya G.A., Vishnevsky A.G., Darsky L.A. \& Sifman R.I. (1977). Skolko detei budet v sovetskoi semie (rezultaty obsledovaniia). [How many children will be in the Soviet family (survey results)]. Moscow: Statistika [in Russian].

3. Belova V.A. \& Darsky L.E. (1972). Statistika mhenii v izuchenii rozhdaiemosti. [Statistics of opinions in the study of fertility]. Moscow: Statistika [in Russian].

4. Berrington A. (2004). Perpetual postpones? Women's, men's and couple's fertility intentions and subsequent fertility behaviour. Population Trends 117.

5. Goldstein J., Lutz W., Testa M. R. (2003). The Emergence of Sub Replacement Family Size Ideals in Europe. European Demographic Research papers 2.

6. Kreyenfeld M. (2005). Economic uncertainty and fertility postponement. Evidence from German panel data. MPIDR Working paper WP 2005-034.

7. Letablier M.-T. Thevenon O. (2009). Trends in fertility and the effectiveness of policies for the realisation of family projects. The Cost of Raising Children and the Effectiveness of Policies to Support Parenthood in European Countries: A Literature Review. European Commission.

8. Liefbroer A.C. (2009) Changes in fertility size intentions across young adulthood: a life-course perspective. European Journal of Population. 25(4).

9. Lutz W., SkirbekkV., Testa M.R. (2006). The low fertility trap hypothesis. Forces that may lead to further postponement and fewer births in Europe. Vienna Yearbook of Population Research, 2006.

10. Miller W. B. (2011). Differences between fertility desires and intensions: implications for theory, research and policy. Reproductive decision-making. Vienna Yearbook of Population Research. Vol. 9.

11. Morgan S. P. (2001). Should fertility intentions inform fertility forecasts? The Direction of Fertility in the United States.

12. Noack T., Ostby L. (2002). Free to Choose - but Unable to Stick to It. Dynamics of Fertility and Partnership in Europe 2. New York, Geneva: United Nations. 
13. Phaile A., Solaz A. (2012). The influence of employement uncertainty on childbearing in France: A tempo or quantum effect? Demographic Research. Vol. 26/1.

14. Philipov D., Thevenon O., Klobas J., Bernardi L., Liefbroer A. (2009). Reproductive decision-making in a macro-micro perspective (REPRO): State-of-the-art review. European Demographic Research Papers 1.

15. Rossier C. Brachet $S$., Salles A. (2011). Family policies, norms about gender roles and fertility decisions in France and Germany. Reproductive decision-making. Vienna Yearbook of Population Research. Vol. 9.

16. Sobotka T. (2011). Reproductive decision-making in a macro-micro perspective (REPRO): Synthesis and Policy Implications. European Demographic Research Papers 1.

17. Testa M. R. (2012). Family size in Europe: Evidence from the 2011 Eurobarometer Survey. European Demographic Research Papers. No 2. Vienna Institute of Demography of the Austrian Academy of Sciences.

18. Testa M. R., Sobotka T., Morgan P. S. (2011). Reproductive decision-making: towards improved theoretical, methodological and empirical approaches. Reproductive decision-making. Vienna Yearbook of Population Research. Vol. 9.

19. Testa M.R., Grilli L. (2009). The effects of childbearing regional contexts on ideal family size in Europe: A multilevel analysis. European Demographic Research Paper. Vienna Institute of Demography of the Austrian Academy of Sciences,

Стаття надійшла до редакції журналу 10.12.2014.

\section{В.В. Станкунене,}

проф. д-р, провідний науковий співробітник, Центр соціальних досліджень Литви,

вул. А. Гоштауто 11, ЛТ-01108, Вільнюс, Литва

E-mail: v.stankuniene@smf.vdu.lt

М.А. Баубліте,

науковий співробітник, Центр соціальних досліджень Литви,

вул. А. Гоштауто 11, ЛТ-01108, Вільнюс, Литва

E-mail: m.baublyte@smf.vdu.lt

\section{СОЦІАЛЬНО-ДЕМОГРАФІЧНІ ВІДМІННОСТІ РЕПРОДУКТИВНИХ УСТАНОВОК В ЛИТВІ В УМОВАХ НИЗЬКОЇ НАРОДЖУВАНОСТІ ТА ЕКОНОМІЧНИХ ЗМІН}

За останні двадцять років значне зниження і збереження низької народжуваності в Литві супроводжується і зниженням репродуктивних установок. Бажане і очікуване число дітей знизилося набагато нижче рівня, необхідного для простого відтворення населення. Репродуктивні установки сильно, а в умовах економічного спаду ще в більших розмірах, розрізняються за соціальнодемографічними групами населення (за віком, освітою, зайнятістю, місцем проживання). Особливо низькими показниками очікуваного числа дітей виділяються чоловіки 3 низькою освітою, безробітні, які живуть на селі і в малих містах.

Ключові слова: народжуваність, репродуктивні установки, соціально-демографічні відмінності народжуваності, Литва.

\section{В.В. Станкунене,}

проф., Д-р, ведущий научный сотрудник Центр социальных исследований Литвы,

Ул. А. Гоштауто 11, ЛТ-01108, Вильнюс, Литва

E-mail: v.stankuniene@smf.vdu.lt

М.А. Баублите,

научный сотрудник, Центр социальных исследований Литвы,

ул. А. Гоштауто 11, ЛТ-01108, Вильнюс, Литва

E-mail: m.baublyte@smf.vdu.lt

СОЦИАЛЬНО-ДЕМОГРАФИЧЕСКИЕ РАЗЛИЧИЯ РЕПРОДУКТИВНЫХ УСТАНОВОК 


\section{В ЛИТВЕ В УСЛОВИЯХ НИЗКОЙ РОЖДАЕМОСТИ И ЭКОНОМИЧЕСКИХ ИЗМЕНЕНИЙ}

За последние двадцать лет значительное снижение и сохранение низкой рождаемости в Литве сопровождается и снижением репродуктивных установок. Желаемое и ожидаемое число детей упало гораздо ниже уровня, нужного для простого воспроизводства населения. Репродуктивные установки сильно, а в условиях экономического спада ещё в больших размерах, различаются по социально-демографическим группам населения (по возрасту, образованию, занятости, месту жительства). Особенно низкими показателями ожидаемого числа детей выделяются мужчины с низким образованием, безработные, живущие на селе и в малых городах.

Ключевые слова: рождаемость, репродуктивные установки, социально-демографические различия рождаемости, Литва.

\section{Stankuniene,}

Prof. Dr., leading researcher, Lithuanian Social Research Centre,

Vilnius, Lithuania, Gostauto str. 11, LT-01108, Vilnius, Lithuania

E-mail: v.stankuniene@smf.vdu.lt

\section{Baublyte}

Researcher, Lithuanian Social Research Centre,

Vilnius, Lithuania,

Lithuanian Social Research Centre, Vilnius, Lithuania

Gostauto str. 11, LT-01108, Vilnius, Lithuania

E-mail: m.baublyte@smf.vdu.lt

\section{SOCIODEMOGRAPHIC DIFFERENCES OF FERTILITY INTENTIONS IN LITHUANIA IN THE CONTEXT OF LOW FERTILITY AND ECONOMIC INSTABILITY}

The research aims to investigate sociodemographic differences of fertility intentions in Lithuania within the context of lowering and low fertility and changing economic situation. To reveal the dynamics of fertility intentions the findings obtained from the surveys carried out in Lithuania over the last fifteen years: international longitudinal Generations and Gender Surveys (two waves in Lithuania conducted in 2006 and 2009), international Fertility and Family Surveys (in Lithuania conducted in 1994-1995), international Population Policy Acceptance Study (in Lithuania conducted in 2001) and the national survey Needs of Family Policy (conducted in 2010) have been used for the analysis.

Within the last twenty years, a greatly lowered and persisting low fertility in Lithuania has been accompanied by changes in fertility intentions as well. The results of descriptive analysis in assessing the attitudes on the number of children desired and intended to have and in estimating the likelihood of plans for an(other) child within the next three years show that over the last fifteen years not only the fertility rates in Lithuania have dropped significantly, but also have been going down fertility intentions (desired and intended number of children), which have fallen well below the replacement level. However within the context of the overall downturn of fertility intentions, the changes in different sociodemographic groups (by age, education, employment status, residence) have been occurring in different ways. By fertility intentions, subpopulations with a lower and strongly economic fluctuation-susceptible level are revealed, which include low-educated men, unemployed men and village and small town residents. Childbearing intentions of men living in the capital are high (on replacement level) and remain practically stable within the context of macroeconomic fluctuations. Differences of women fertility intentions by sociodemographic groups are smaller and their reaction to macro-economic changes is rather controversial. The analysis of logistic regression performed has revealed the greatest correlation of the fertility intentions to have children with age and residence. Men and women living in capital city express much higher fertility intentions than the respondents in other residences. The greatest sociodemographic differences are seen in short-term (during the next three years) fertility intentions which are quick to respond to the macro economic situation.

Keywords: fertility; fertility intentions; sociodemographic fertility differences, Lithuania 